\title{
Mot økt folkelig innflytelse? Desentralisering og lokaldemokrati i Ukraina
}

\author{
Aadne Aasland \\ Seniorforsker/Forsker 1, By- og regionforskningsinstituttet NIBR, OsloMet - \\ Storbyuniversitetet
}

\begin{abstract}
Towards greater popular participation? Decentralization and local democracy in Ukraine

The article analyses the results of a nationally representative survey on local democracy conducted in Ukraine in the autumn of 2017, offering insights into attitudes towards local authorities and ongoing decentralization reforms, as well as participation in local politics. The survey shows that people have very low trust in the authorities, but more trust in them than in national institutions. Respondents feel that they have little influence on local politics and that local authorities do not take their opinion into account. On the other hand, the majority report being active in various forms of local political activity. Further, there is considerable support of decentralization reforms; people have already noted certain local improvements since the decentralization reform was launched in 2015. Differences among the several geographical regions of Ukraine are small. Survey findings are explained through three analytical frameworks that emphasize the historical heritage, important economic and political conditions, and structural adjustment to European institutions.
\end{abstract}

Keywords: Ukraine, local democracy, decentralisation, survey

\section{Innledning}

Ukrainas mer enn 40 millioner innbyggere har sammensatte og kryssende regionale, etniske, språklige og religiøse identiteter. Sosioøkonomiske forhold varierer også mye mellom ulike deler av landet (Sasse 2014). Men i hvilken grad har folk flest innflytelse på utviklingen i byen eller kommunen der de bor? Hvordan er forholdet mellom innbyggerne og de lokale myndighetene i ulike deler av Ukraina? Og, viktigst, hvordan kan man forklare tilstanden til landets lokaldemokrati? Dette er spørsmål som denne artikkelen søker å belyse gjennom analyse av data fra en landsomfattende lokaldemokratiundersøkelse gjennomført i Ukraina høsten 2017 og gjennom å anvende analytiske rammeverk som kan forklare utviklingen av lokaldemokratireformer i postkommunistiske transisjonsland.

\footnotetext{
^Kontaktinformasjon: Aadne Aasland. epost: aadnea@oslomet.no 
Fra Sovjetunionens oppløsning og fram til den såkalte Majdan-revolusjonen i 2013-14, da det beryktede Janukovitsj-regimet ble kastet, var det liten iver blant styresmaktene for å gjøre noe med den sentraliserte styreformen som hang igjen etter Sovjettiden. Hvilken politisk farge presidenten eller regjeringen hadde, spilte liten rolle. De gjorde uansett lite eller ingenting for å gi fra seg kontroll ved å desentralisere makten. I realiteten ble landet heller ytterligere sentralisert (Aasland \& Lyska 2016). Samtidig har regionale økonomiske og politiske eliter hele tiden hatt stor innflytelse på landets utvikling i tett samspill med nasjonale politikere.

Etter Majdan-opprørets folkelige mobilisering og krav om demokratisering, opplevde myndighetene økt press for desentralisering. Og i 2015 begynte iverksettelsen av mer grunnleggende desentraliseringsreformer (Levitas \& Diikic 2017). ${ }^{1}$ I stedet for en føderal modell, som ville kunne medføre krav om økt regionalt selvstyre og fare for ytterligere avskalling, har Ukraina valgt en modell der makt og ressurser overføres til det lokale kommunale nivået. Innflytelsen til distrikter og regioner svekkes parallelt.

Dette krever kommuner som er store nok og med tilstrekkelige ressurser til å kunne ivareta sine utvidede ansvarsområder. I et land som opprinnelig hadde mer enn 11.000 til dels svært små kommuner, er kommunesammenslåing en av reformens grunnpilarer. Foreløpig har slike sammenslåinger skjedd frivillig og gjennom bruk av betydelige økonomiske insentiver fra statens side. Målet er å nå et antall på rundt 1.500 kommuner, men i så fall må farten på kommunesammenslåinger øke. I mars 2018 var knapt 3.400 kommuner blitt slått sammen til 725 større sammenslåtte kommuner (Umland mfl. 2018).

Det er mange skjær i sjøen. Lokale eliter på distriktsnivå kjemper mot å gi fra seg makt til de sammenslåtte kommunene (Makarenko 2017). Regjeringen har også støtt på store problemer i parlamentet med å forankre reformen i grunnloven, noe som gir nasjonale politikere muligheten til å reversere den senere (Levitas \& Djikic 2017). Videre har en del svakt utviklede områder med lave skatteinntekter kommet dårlig ut. Noen små og fattige kommuner er ikke attraktive partnere og har ikke funnet noen å slå seg sammen med.

På den annen side får kommunene nå beholde en mye større andel av sine skatteinntekter og kan i større grad selv velge hva disse skal brukes til. Dette gjør at desentraliseringsreformen både av nasjonale og internasjonale eksperter er blitt fremhevet som en av de mest vellykkede reformer i Ukraina siden Janukovitsj-regimet ble styrtet (Peleschuk 2015). Desentraliseringsreformen er også den av de reformene som har vært gjennomført i denne perioden, som flest ukrainske innbyggere peker ut som den mest vellykkede (Ilko Kucheriv Democratic Initiative Foundation 2018).

\footnotetext{
${ }^{1}$ I august 2014 vedtok det utgående ukrainske parlamentet loven «Om samarbeid mellom lokalsamfunn» (lovteksten er tilgjengelig på engelsk på http://zakon0.rada.gov.ua/laws/anot/en/1508-18; lesedato 17. oktober 2018), og i februar 2015 ble loven «Om frivillig konsolidering av territorielle enheter» vedtatt av det nye parlamentet (tilgjengelig på http://zakon.rada.gov.ua/laws/show/157-viii (på ukrainsk). Lesedato 17. oktober 2018).
} 


\section{AADNE AASLAND}

Selv om det ikke nødvendigvis er noen en-til-en sammenheng mellom desentralisering og lokalt demokrati, er disse som oftest tett sammenvevd (Baldersheim \& Swianiewicz 1996). Desentralisering bringer staten nærmere borgerne og gjør at myndighetene kan løse sine oppgaver mer effektivt. Den kortere avstanden mellom de styrende og de styrte gjør at det blir enklere å delta og påvirke beslutningene, både gjennom valg og andre former for politisk deltakelse. Borgerne kan videre lettere følge med på både politiske beslutningsprosesser og implementeringen av politikken. Det lokale nivået kan også virke som en motkraft til nasjonale myndigheter og forhindre overkjøring omkring spørsmål av stor regional betydning. På den andre siden kan lokale og regionale autoritære makteliter også undergrave det lokale demokratiet og på den måten bremse demokratiseringsprosesser.

\section{Analytiske rammeverk}

Riktignok er frie og demokratiske valg avgjørende for å fremme folkelig representasjon i styrende organer, men godt gjennomførte valg er ikke tilstrekkelig til å sikre et godt lokaldemokrati. Medlemslandene i Europarådet er blitt enige om 12 prinsipper for hva som kjennetegner godt lokalstyre (Kommunaldepartementet, udatert - se Boks 1). I kortform: Foruten valg kjennetegnes godt lokalstyre av at lokale myndigheter opptrer ansvarlig overfor innbyggerne, er åpne og tilgjengelige, gir tilstrekkelig informasjon og lytter til innbyggernes innspill. For at lokaldemokratiet skal fungere, må innbyggerne ikke bare ha mulighet til å delta; de må delta aktivt i lokale beslutningsprosesser. Mens internasjonale organisasjoner de senere år har gitt Ukraina godkjentstempel på gjennomføringen av de fleste nasjonale og lokale valg, er det lite systematisk kunnskap om tilstanden til ukrainsk lokaldemokrati langs de andre dimensjonene. Denne artikkelen bidrar til forskningslitteraturen på feltet nettopp gjennom å rette søkelyset mot flere av de andre viktige sidene ved lokaldemokratiet.

Boks 1. Europarådets 12 prinsipper for godt lokalstyre

1. Rettferdige valg, representasjon og deltakelse

2. Respons

3. Effektivitet

4. Åpenhet

5. Rettssikkerhet

6. Etikk

7. Kompetanse og kapasitet

8. Innovasjon og åpenhet for forandringer

9. Bærekraft og langsiktighet

10. Sunn finansiell styring

11. Menneskerettigheter, kulturelt mangfold og sosial samhørighet

12. Ansvarlighet 
Hvordan er så tilstanden til det ukrainske lokaldemokratiet? Ett forhold er hva som nedfelles i form av lovverk og prinsipper; et annet er i hvilken grad disse blir fulgt opp i konkret politikk og lokale praksiser. Og dersom det er avstand mellom prinsipper og praksis, kommer spørsmålet om hvorfor det forholder seg slik. Målet med artikkelen er således ikke bare å studere hvordan lokaldemokratiet arter seg i Ukraina sett fra innbyggernes ståsted, men også å søke forklaringer på våre funn. Foruten data av høy kvalitet trengs derfor også gode analytiske rammeverk til å forstå og forklare resultatene.

Illner (2003) har skissert fire delvis konkurrerende rammeverk for hvordan lokaldemokratireformer i postkommunistiske transisjonsland kan forstås. Til tross for at det snart er gått 30 år siden Sovjetunionen brøt sammen og Ukraina ble uavhengig, og den politiske kursen i denne perioden i stor grad har variert mellom ulike ukrainske regjeringer, er det mye som tilsier at Ukraina fortsatt kan betraktes som et transisjonsland. Slik landets myndigheter eksplisitt uttrykker det, er likevel målet å utvikle et demokrati av vestlig type. Samtidig har landets demokratiske utvikling siden Sovjetunionens oppløsning vært haltende, preget av en presidentmakt med svært vide fullmakter, sterk grad av sentralisering og et patron-klient-nettverk. Alle disse faktorene har vært med på å bremse gjennomføringen av reelle demokratireformer (Minakov \& Rojansky 2018).

Illners første rammeverk, som han kaller «the legacies framework», vektlegger den historiske arven og fremhever betydningen av de institusjonelle, strukturelle og kulturelle føringene fra det tidligere regimet. Her er stiavhengighet - at handlingsvalg begrenses av forhold i fortiden som ikke engang trenger å være relevante i dagens situasjon - et sentralt begrep. Forsøk på å deinstitusjonalisere, renske ut makten og få en omstart, for eksempel gjennom folkelige opprør eller sosiale bevegelser, vanskeliggjøres ofte av en innebygd institusjonell treghet.

Det neste rammeverket Illner beskriver, er "the incongruent speeds of change framework» som påpeker og søker å forklare de store forskjellene mellom land med hensyn til tempoet og retningen på reformene. Her vektlegges blant annet betydningen av grunnlovsreform, økonomiske reformer og sivilsamfunnets stilling.

Så følger "the structural adaptation framework», der søkelyset rettes mot landenes tilpasning til allerede eksisterende modeller for lokaldemokrati, hovedsakelig hentet fra vesteuropeiske demokratier og med europeiske institusjoner som viktige formidlere av normer og prinsipper. Til slutt beskriver Illner «the modernisation framework», der transisjonen, herunder lokaldemokratireformer, i de postkommunistiske land blir sett på som forsinket tilpassing til "moderne» institusjons-, atferds- og kulturmønstre som er fremtredende i mer «utviklede» land.

Med mulig unntak av moderniseringsrammeverket, som etter mitt syn representerer et altfor rettlinjet og snevert syn på hva som er utvikling og modernitet, har de tre øvrige rammeverkene relevans for utviklingen av lokaldemokratireformer i Ukraina. Etter en gjennomgang av resultatene av spørreundersøkelsen vil jeg derfor søke å hente innsikter fra de tre rammeverkene for å fange opp noe av den spenningen 


\section{AADNE AASLAND}

som gjør seg gjeldende når Ukraina nå skal desentralisere og gi mer innflytelse til det lokale nivået og til innbyggerne der.

\section{Data og metode}

Som en del av et større samarbeidsprosjekt om desentralisering og lokaldemokrati i Ukraina ${ }^{2}$ gjennomførte ukrainske og norske forskere høsten 2017 en landsomfattende lokaldemokratiundersøkelse blant ukrainske innbyggere. ${ }^{3}$ Undersøkelsen gir et innblikk i tilstanden til lokaldemokratiet og oppslutningen om desentraliseringsreformen i Ukraina.

Undersøkelsen ble gjennomført i form av telefonintervjuer av et profesjonelt meningsmålingsinstitutt, Operatyona Sociologija, lokalisert i Dnipro. Instituttet har tilgang til en database med alle mobilnumre som potensielt kan være bruk i Ukraina (det er høy grad av mobiltelefondekning i landet, og mobiltelefoner er i dag mye mer brukt enn hjemmetelefon). Numre ble så tilfeldig trukket fra denne databasen. ${ }^{4}$ Metoden har vært kvalitetstestet ved å sammenligne resultater fra meningsmålinger like i forkant av et valg med det faktiske valgresultatet, og viser en høy grad av overensstemmelse. Resultatene gir videre et representativt utvalg med hensyn til geografisk spredning i Ukraina, størrelse på hjemkommune, alder og kjønn. En feilmargin på rundt $+/-3 \%$ må imidlertid påregnes.

I analysen gjennomfører vi flere regresjonsanalyser. De uavhengige variablene brukt i disse analysene (bortsett fra institusjonstillit, som blir behandlet separat i et av underkapitlene) er beskrevet nærmere i et appendiks. På kartet under fremgår det også hvordan landet er delt i fem regioner: Øst-, Vest-, Nord-, Sør- og SentralUkraina. I en grovere inndeling $\mathrm{i}$ «øst» og «vest» som bygger på tradisjonelle kulturelle og politiske skillelinjer, ville til sammenligning «øst» omfattet sør og øst i vår inndeling, mens «vest» ville omfattet vest, nord og sentrale deler av Ukraina.

\footnotetext{
${ }^{2}$ Prosjektpartnere er den ukrainske kommuneorganisasjonen Assotsiatsiya mist Ukrainy (Association of Ukrainian Cities, AUC), den norske kommunesektorens organisasjon KS og By- og regionforskningsinstituttet NIBR ved OsloMet - Storbyuniversitetet. For mer om prosjektet, se http:// www.ks.no/fagomrader/samfunn-og-demokrati/internasjonalt-samarbeid/ks-in-ukraine/ (Lesedato 17. oktober 2018). Prosjektet er finansiert av det norske Utenriksdepartementet. For mer om undersøkelsen og resultatene (på ukrainsk), se AUC (2018).

${ }^{3}$ Undersøkelsen ble giennomført i hele landet, bortsett fra på Krim og i de selverklærte republikkene i Luhansk og Donetsk.

${ }^{4}$ Basert på alle mobiloperatører vet man at det er ca. 110 millioner potensielle mobilnummer $\mathrm{i}$ Ukraina, hvorav ca. 55 millioner er i bruk. Meningsmålingsbyrået genererte først 21.000 tilfeldige numre, hvorav ca. 11.000 viste seg å være i bruk da intervjuerne ringte. Imidlertid var det kun ca. 4.000 som tok telefonen, og av disse igjen sa 1034 respondenter seg villige til å bli med på undersøkelsen.
} 


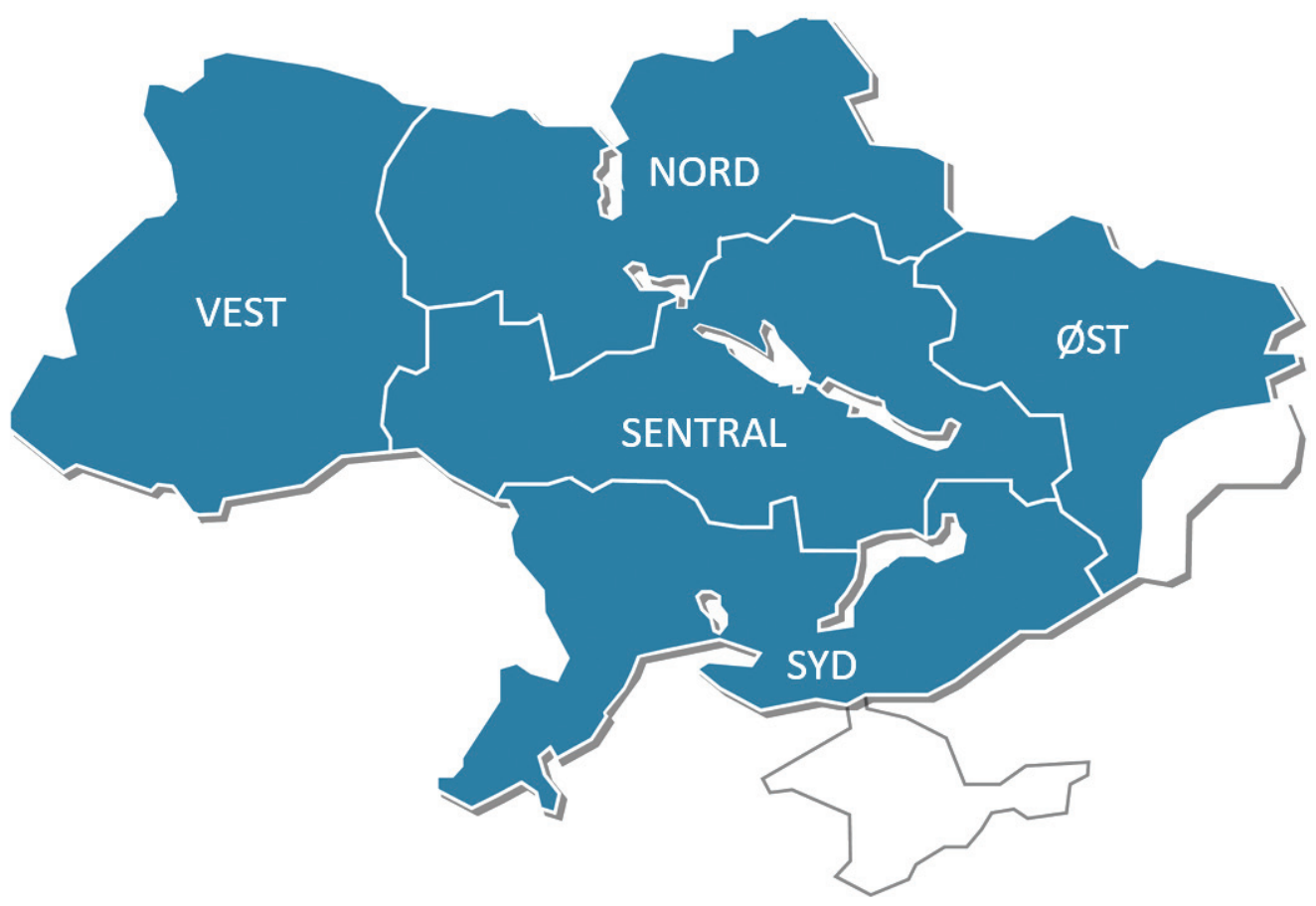

\section{Hvordan vurderer innbyggerne sine lokale myndigheter?}

Innbyggerne i Ukraina mener de har liten innflytelse på lokale beslutninger. På et spørsmål om innbyggernes grad av innflytelse på lokale beslutninger, svarer to av tre respondenter at de overhodet ikke har noen innflytelse, mens ytterligere $20 \%$ svarer at de har liten innflytelse. Kun de resterende $13 \%$ mener de har en del eller stor innflytelse på lokale beslutninger (Figur 1).

På spørsmål om innbyggernes mening blir tatt i betraktning av lokale myndigheter, svarer $59 \%$ at de ikke blir det eller at de blir det i liten grad, en knapp fjerdedel er usikre mens bare $18 \%$ svarer at myndighetene tar hensyn til innbyggernes meninger i betydelig eller i stor grad (Figur 2).

Litt mer positive er svarene når det gjelder hvorvidt myndighetene er tilstrekkelig åpne om hvordan offentlige midler fordeles: $32 \%$ er enten helt eller delvis enige i at det er åpenhet om fordelingen. Hele $46 \%$ er helt eller delvis enige i et utsagn om at myndighetene fordeler ressursene på en effektiv måte, og $49 \%$ sier seg enige i at lokale myndigheter gir nok informasjon til innbyggerne om viktige spørsmål. Bare når det gjelder synet på om myndighetene lytter til innbyggerne, er det et flertall som gir en overveiende positiv vurdering (Figur 3).

La oss så se på hvem som gir best attest til lokaldemokratiet der de bor. Vi laget en skala basert på de nevnte sju vurderingene (resultatene fra figurene 1, 2 og 3) av lokale myndigheter der en høy score er stor grad av tilfredshet, mens en lav score 


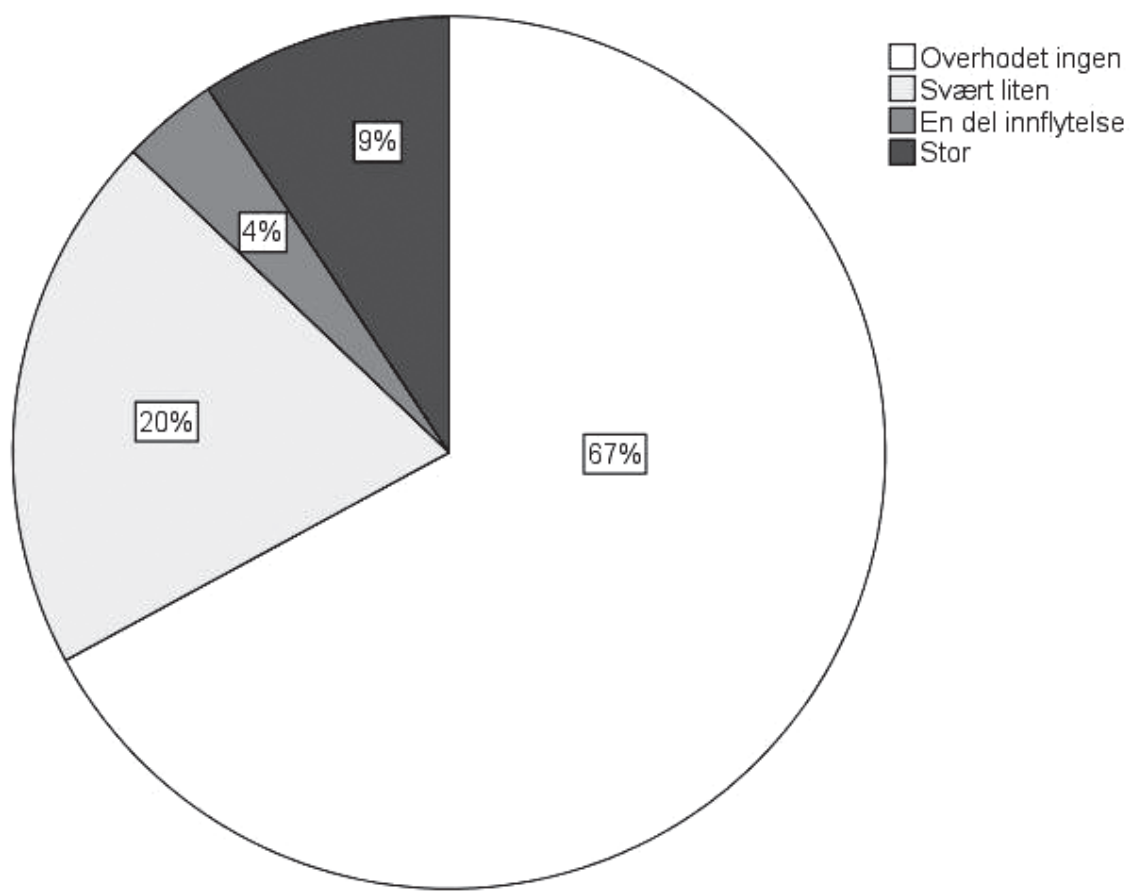

Figur 1. I hvilken grad har innbyggerne i kommunen innflytelse på lokale beslutninger? Prosent.

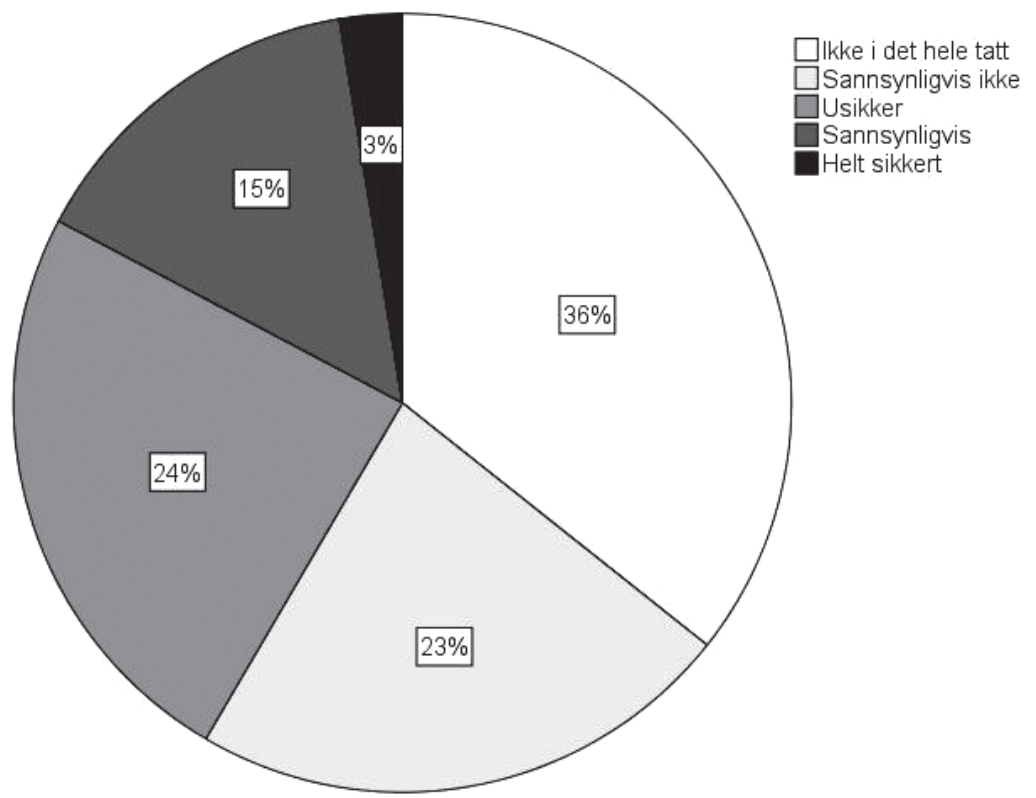

Figur 2. Tar lokale myndigheter innbyggernes meninger i betraktning når de fatter beslutninger? Prosent. 


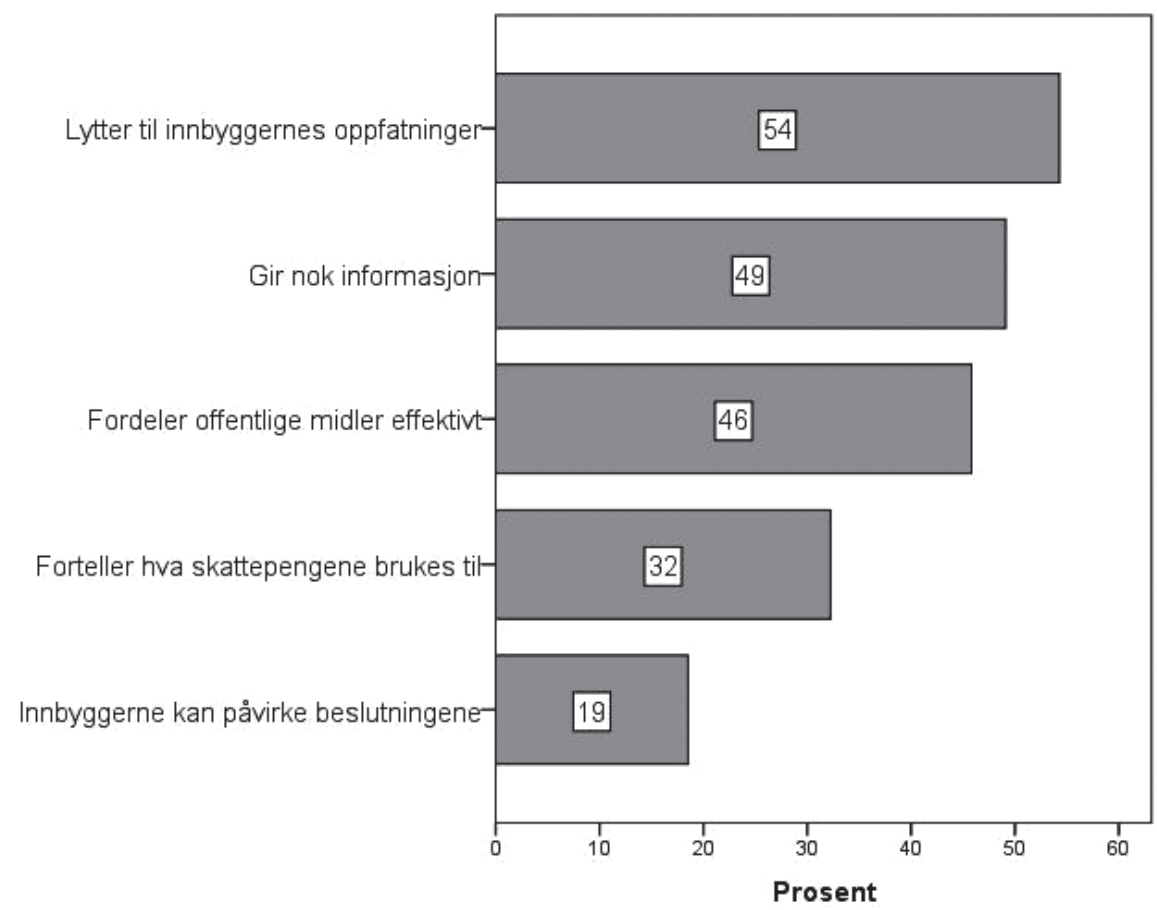

Figur 3. Grad av enighet med utsagn om lokale myndigheter. Prosentandel som svarer enig eller svært enig.

betyr misnøye. Reliabilitetsanalyse gir en høy korrelasjon mellom de sju variablene (Chronbach's Alpha $=0,82$ ), som viser at skalaen måler ett fenomen, som vi tolker som å være kvaliteten på lokaldemokratiet.

Vi utførte deretter lineær regresjon med scoren på lokaldemokratiskalaen som den avhengige variabelen. På denne måten kan vi finne effekten av ulike variabler samtidig som vi kontrollerer for andre variabler i modellene. I den første modellen (M1, se Tabell 1) så vi kun på effekten av kjønn, alder, utdanningsnivå og subjektiv levestandard. Av disse er det kun levestandard som har en statistisk signifikant effekt, og denne er positiv. Jo bedre levestandard respondenten har, jo mer tilbøyelig er han eller hun med andre ord til å gi en positiv vurdering av lokaldemokratiet der vedkommende bor. I modell 2 (M2) så vi i tillegg på effekten av bosted, både hvor i landet respondenten bor og type bosted (på landet/i en landsby, $i$ en liten by, i en større by eller i en regional hovedstad). Sammenlignet med kontrollgruppen «Nord» gir innbyggerne både i Øst- og Vest-Ukraina en signifikant bedre vurdering av sine lokale myndigheter, selv om forskjellene er relativt små. Type bosted har derimot ingen statistisk signifikant effekt på vurderingen av lokaldemokratiet. 
Tabell 1. Multippel lineær regresjon med tre modeller. Avhengig variabel: score på lokaldemokratiskala. Standardiserte Beta-koeffisienter ${ }^{5}$

\begin{tabular}{lccc}
\hline & M1 & M2 & M3 \\
\hline Alder & 0,05 & 0,05 & 0,01 \\
Kjønn (vs. kvinne) & 0,01 & 0,01 & 0,04 \\
Utdanning (fire kategorier) & 0,02 & 0,04 & $-0,01$ \\
Levestandard (fire kategorier) & $0,12^{\star \star}$ & $0,13^{\star \star}$ & 0,03 \\
Sentral-Ukraina (vs. nord) & & 0,08 & 0,04 \\
Sør-Ukraina (vs. nord) & & 0,05 & 0,06 \\
Øst-Ukraina (vs. nord & & $0,11^{\star \star}$ & 0,03 \\
Vest-Ukraina (vs. nord) & $0,09^{\star}$ & 0,05 \\
Urbanitetsgrad (fire kategorier) & $-0,05$ & 0,04 \\
Institusjonstillit (indeks) & & & $0,55^{\star \star}$ \\
Interesse for lokalpolitikk (fire kategorier) & & & $0,08^{\star \star}$ \\
Lokal deltakelse (indeks) & & & $0,12^{\star \star}$ \\
Justert R & & & $\mathbf{0 , 3 4}$ \\
\hline
\end{tabular}

$\star \star$ Signifikant på 0,01-nivå

^Signifikant på 0,05-nivå

I den siste modellen (M3) tok vi også med noen variabler som vi fant det sannsynlig at kunne ha betydning for utfallet på den avhengige variabelen: tillit til institusjoner, uttrykt interesse for lokalpolitikk samt lokal deltakelse. I denne modellen får vi store utslag. En justert $\mathbf{R}^{2}$ på 0,34 viser at de uavhengige variablene i modellen forklarer en drøy tredjedel av den variasjonen vi finner mellom svarene på den avhengige variabelen. Klart størst effekt har tillit til institusjoner. Figur 4 viser at graden av tillit til ulike institusjoner i Ukraina må anses for å være eksepsjonelt lav, selv om tilliten til lokale myndigheter er noe høyere enn til statlige myndigheter og en del institusjoner på statlig nivå. Våre resultater samsvarer med resultater fra European Value Survey, som viser at Ukraina er blant de land i Europa der befolkningen har aller lavest tillit til politiske myndigheter (van der Meer \& Hakhverdian 2017). Rothstein (2004) slår fast at tillit til myndighetene er en viktig forutsetning for å etablere effektive institusjoner, og manglende tillit blir sett som en årsak til demokratisk underskudd i flere postsosialistiske land. Dermed er trolig den lave tilliten til myndighetene en medvirkende grunn til at folk har et relativt pessimistisk syn på kvaliteten på lokaldemokratiet i Ukraina. Men den kausale retningen kan også være motsatt: Dårlig kvalitet på myndighetsutøvelsen kan forsterke den lave tilliten i samfunnet (Aasland mfl. 2012). Også de to andre variablene som ble inkludert i modell 3, har som forventet en signifikant og positiv effekt på vurderingen av lokaldemokratiet. Viktigst av de to er nivået på

\footnotetext{
${ }^{5}$ Av plasshensyn er variablene utdanning, levestandard, urbanitetsgrad og politisk interesse i denne og etterfølgende modeller tatt inn som kontinuerlige variabler. Vi har imidlertid testet om resultatet ville vært et annet om vi hadde behandlet variablene som kategoriske og fant at forskjellene er svært små og ikke statistisk signifikante.
} 
deltakelse på lokalt nivå, som vi skal se nærmere på i neste del. Men uttrykt interesse for lokalpolitikk er også positivt korrelert med den avhengige variabelen.

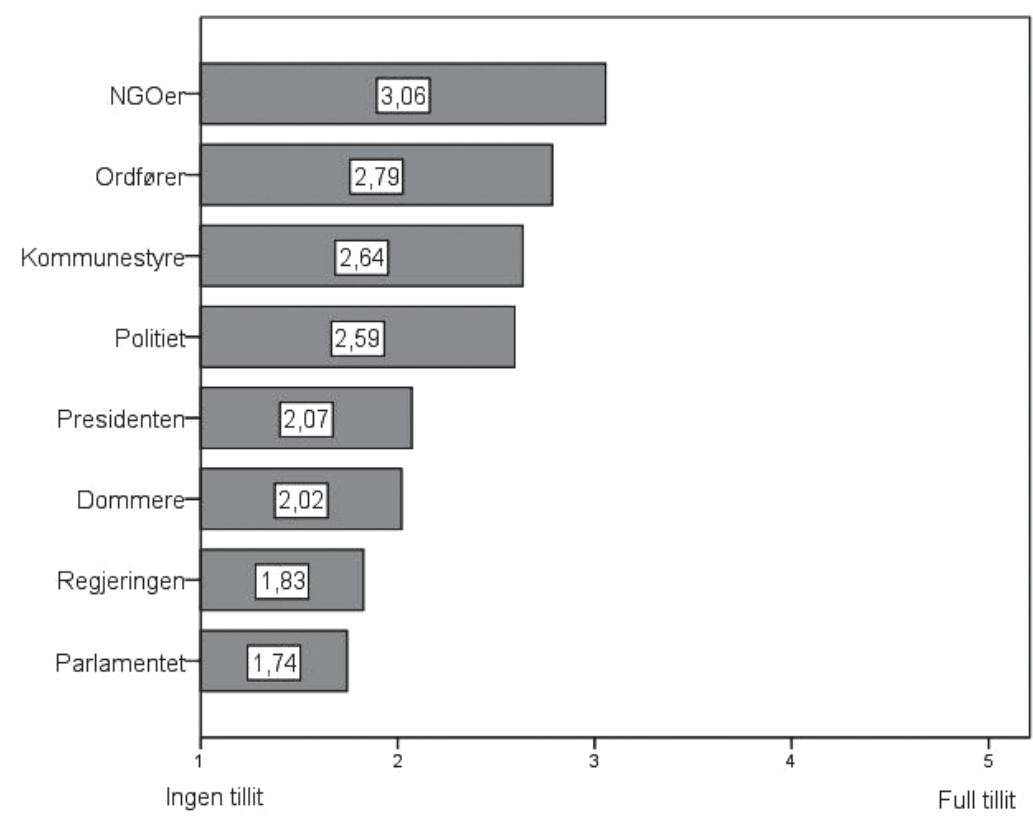

Figur 4. Tillit til institusjoner i Ukraina. Gjennomsnittsscore på en skala fra 1 (ingen tillit) til 5 (full tillit). $\mathrm{N}=1039$ («vet ikke» og ikke svart er tatt ut).

Det er verdt å merke seg at de statistisk signifikante forskjellene vi fant mellom ulike grupper i modellene 1 og 2 , forsvant da vi introduserte de nye variablene. De moderate forskjellene mellom regioner og folk med ulik levestandard med hensyn til vurderingen av lokaldemokratiet, er derfor trolig heller forklart med ulik grad av tillit, deltakelse eller politisk interesse (eller en kombinasjon av disse) og at disse ikke er jevnt fordelt mellom regioner og ulike inntektskategorier.

\section{Hvem deltar lokalt?}

Et godt lokaldemokrati forutsetter aktive innbyggere som deltar i samfunnslivet. Lokal deltakelse kan ta mange forskjellige former. Her skal vi se på deltakelse både gjennom valg, deltakelse i lokalpolitikken og i sivilsamfunnet for øvrig. Valgdeltakelsen i det siste lokalvalget i Ukraina (2015) var på 46,2 \%, noe som er ganske gjennomsnittlig i europeisk sammenheng. Figur 5 viser andelen av respondenter som oppgir å ha deltatt i ulike former for politisk aktivitet på lokalt nivå i løpet av det siste året. Et flertall på 56 \% har minst deltatt i én av disse aktivitetene. Dette er en betydelig økning fra 2014 da vi gjennomførte en tilsvarende lokaldemokratiundersøkelse i Ukraina. Den forrige undersøkelsen ble kun gjennomført i 20 byer, så den er derfor ikke direkte sammenlignbar, men resultatene fra den viser økt aktivitet 
med hensyn til nesten alle former for deltakelse, med unntak av protester og demonstrasjoner. Det siste er ikke overraskende gitt tidspunktet for denne undersøkelsen, som var på forsommeren 2014, ikke lenge etter Majdan-revolusjonen.

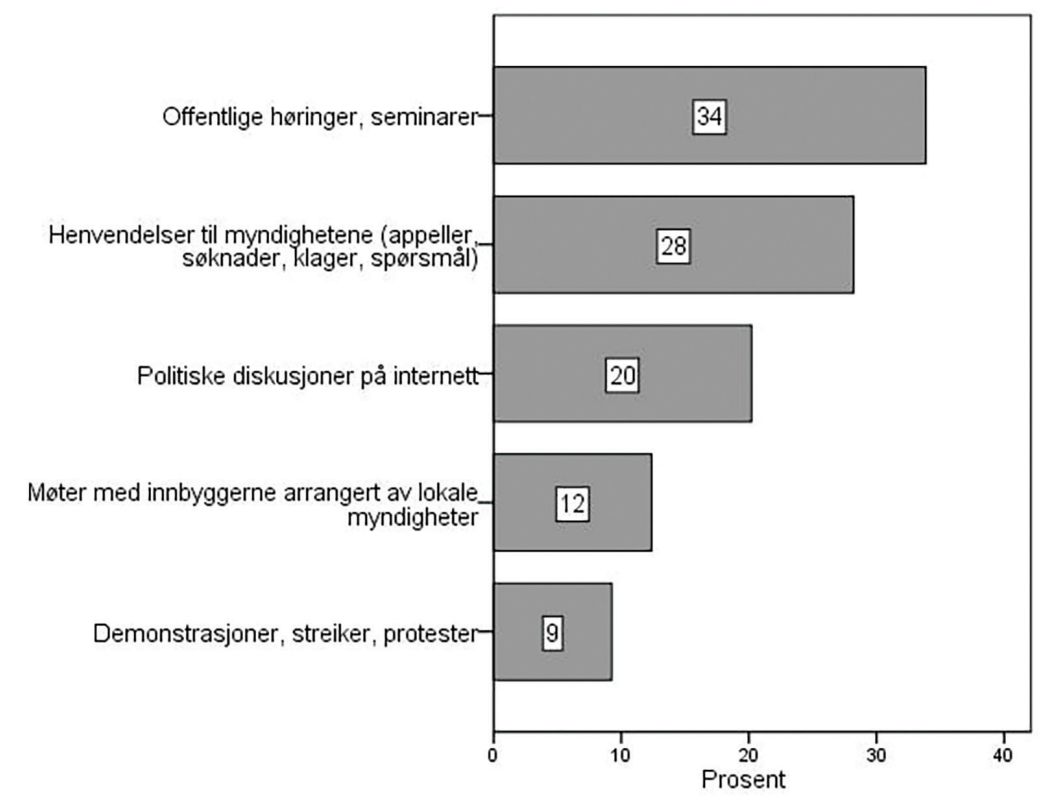

Figur 5. Deltakelse i aktiviteter lokalt. Prosentandel som sier de har deltatt i løpet av de siste 12 måneder.

Undersøkelsen viser videre at $6 \%$ oppgir å være medlem av en ikke-statlig organisasjon (NGO), mens $3 \%$ hevder å være medlem av et politisk parti. De som sier at de er aktive i organisasjonen eller partiet, utgjør henholdsvis $4 \%$ og $1 \%$ av respondentene. Det kan virke som et tilsynelatende paradoks at tilliten til NGO er forholdsvis høy, samtidig som folk flest deltar lite i organisasjonslivet. Tilliten har trolig sammenheng med at sivilsamfunnet ble vitalisert som følge av oransje- og Majdan-revolusjonene samt at innflytelsen vanlige innbyggere kan ha over samfunnsutviklingen gjennom mobilisering, er blitt mer synlig. Når likevel såpass få velger å delta selv, kan dette ha sammenheng med relativt lite tradisjon for sivilsamfunnsdeltakelse samt manglende tid, ressurser og tro på at man kan nå fram gjennom ordinært organisasjonsliv.

På samme måte som vi ønsket å finne ut hvem som er mest tilfreds med lokaldemokratiet, gjennomførte vi en lineær regresjon med lokal deltakelse som den avhengige variabelen. Vi laget en indeks som inkluderte de ulike formene for deltakelse, uavhengig av om disse korrelerte med hverandre eller ikke. En reabilitetsanalyse ga en Chronbach's Alpha på 0,59, noe som er litt for lavt til å antyde at vi bare måler ett fenomen. Likevel valgte vi å beholde indeksen fordi den gir et reelt uttrykk for den store bredden i folks deltakelse lokalt. 
Tabell 2. Multippel lineær regresjon med tre modeller. Avhengig variabel: deltakelsesindeks. Standardiserte Beta-koeffisienter

\begin{tabular}{lccc}
\hline & M1 & M2 & M3 \\
\hline Alder & $0,12^{\star \star}$ & $0,12^{\star \star}$ & 0,04 \\
Kjønn (vs. kvinne) & 0,05 & 0,04 & 0,02 \\
Utdanning (fire kategorier) & $0,09^{\star \star}$ & $0,12^{\star \star}$ & $0,06^{\star}$ \\
Levestandard (fire kategorier) & 0,06 & $0,08^{\star}$ & 0,05 \\
Sentral-Ukraina (vs. nord) & & $0,08^{\star}$ & 0,04 \\
Sør-Ukraina (vs. nord) & 0,05 & 0,04 \\
Øst-Ukraina (vs. nord) & & 0,03 & 0,02 \\
Vest-Ukraina (vs. nord) & 0,07 & 0,04 \\
Urbanitetsgrad (fire kategorier) & & $-0,13$ & $-0,13$ \\
Institusjonstillit (indeks) & & & $-0,05$ \\
Interesse for lokalpolitikk (fire kategorier) & & & $0,35^{\star \star}$ \\
Lokaldemokrati-score (indeks) & & & $0,133^{\star \star}$ \\
Justert R & & & $\mathbf{0 , 1 7}$ \\
\hline
\end{tabular}

$\star \star$ Signifikant på 0,01-nivå

*Signifikant på 0,05-nivå

I modell 1 (se tabell 2), som kun inneholder de demografiske variablene kjønn og alder samt utdanning og levekår, ser vi at alder har en positiv og statistisk signifikant effekt på lokal deltakelse. Likeledes er utdanning, som ventet, positivt korrelert med den avhengige variabelen. Kjønn og levestandard har derimot ingen signifikant effekt. I modell 2 tar vi inn variabler for region og type bosted. Igjen finner vi at hvor i landet man bor, har liten betydning for deres tilbøyelig til å delta lokalt. Etter å ha kontrollert for de andre variablene i modellen, ser vi imidlertid at folk som bor i sentrale deler av landet har litt høyere deltakelse. Noe overraskende finner vi en sammenheng mellom lokal politisk deltakelse og grad av urbanitet: nemlig at jo større byene eller tettstedene er, jo mindre sannsynlig er det at folk deltar. Når det derimot gjelder deltakelse i samfunnet, er situasjonen den motsatte. Når det kan virke som om innbyggernes deltakelse i lokalpolitikken er størst på mindre steder, er dette muligens fordi det er kortere avstand til myndighetene der.

I modell 3 tar vi igjen inn variabler som vi antar har betydning for folks tilbøyelighet til å delta: tillit til institusjoner, politisk interesse og vurdering av kvaliteten på lokaldemokratiet (den samme skalaen som ble brukt tidligere). Det er verdt å merke seg at mens tillit til institusjoner viste seg å være av svært stor betydning for respondentenes vurdering av lokaldemokratiet, har tillit til institusjoner faktisk en ørliten negativ (dog ikke statistisk signifikant) effekt på lokal deltakelse. Det kan således virke som folk velger å delta uavhengig av hvilken tillit de har til 
myndighetene. Viktigst for graden av deltakelse er om innbyggerne er interesserte i lokalpolitikk eller ikke. Her gir politisk interesse betydelig positiv effekt. Videre er folk mer tilbøyelige til å delta jo bedre de vurderer at lokaldemokratiet fungerer.

Effekten av alder forsvinner helt og effekten av utdanning reduseres i modellene 2 og 3. Dette skyldes trolig at eldre og høyt utdannede er mer interesserte i lokalpolitikk enn yngre og folk med lite utdanning. Imidlertid opprettholdes betydningen av urban bosetting også etter at variablene i modell 3 blir tatt inn. Modellen for deltakelse er ikke like sterk som modellen for vurdering av lokaldemokratiet, i dette tilfellet er justert $\mathrm{R}^{2} 0.17$, som betyr at moderate 17 prosent av variasjonen i deltakelse kan tilskrives fordelingen på de andre variablene i modellen.

\section{Desentralisering og lokaldemokratireformer: Folkelig oppslutning?}

Som nevnt var tiden overmoden for å desentralisere makten i Ukraina, og siden 2015 har desentraliseringsreformen skutt fart. Det er imidlertid store forskjeller i befolkningen med hensyn til i hvilken grad de oppfatter seg å være informert om de pågående reformene. En fjerdedel sier at de ikke vet noe som helst, $17 \%$ svarer at de vet veldig lite, $38 \%$ sier de vet en god del, mens resten, $20 \%$, «vet alt» om reformene (de $2 \%$ som svarer "vet ikke» eller ikke svarer, er ikke tatt med).

Når det gjelder innbyggernes støtte til reformen, er bildet også nyansert. Tatt i betraktning den lave tilliten til myndighetene og den forholdsvis store misnøyen med lokaldemokratiet, er imidlertid tendensen at folk er mer positivt innstilt til reformen enn vi hadde regnet med. Av de som har svart, er et betydelig flertall tilbøyelig til å støtte reformen: $62 \%$ støtter den enten delvis eller helt, $12 \%$ er nøytrale, mens $26 \%$ er helt eller delvis negative. Hertil kommer imidlertid en større andel som enten svarer "vet ikke» eller ikke svarer, $17 \%$ i alt, og det er et stort sammenfall mellom disse og de som sier at de ikke er informert om reformen.

For å se hvem som gir sin tilslutning til desentraliseringsreformen, gjennomførte vi en logistisk regresjon der vi kun har inkludert de respondentene som enten ga sin tilslutning eller uttrykte motstand mot reformen, mens de nøytrale og vetikke kategorien ble tatt ut. Igjen startet vi med en modell der vi kun tok med sosiodemografiske variabler. Resultatene fremgår av Tabell 3. Her ser vi at menn er mer tilbøyelige til å støtte reformen enn kvinner. Videre går høyere utdanning sammen med reformstøtte. I modell 2 er urbanitetsgrad og kommunens geografiske beliggenhet også tatt med. Resultatene viser at det er noe høyere oppslutning om reformen på mindre steder. Trolig øyner folk som bor på små steder muligheter for bedre tjenester og ressurser, selv om det til nå er de store byene og noen sammenslåtte kommuner som har hatt størst økonomisk utbytte av reformene (Levitas \& Djikic 2017). Det er interessant å merke seg at geografisk plassering i Ukraina ikke gir statistisk signifikante utslag på tilbøyelighet til reformstøtte. 
Tabell 3. Binær logistisk regresjon med tre modeller. Avhengig variabel: støtte til desentraliseringsreformen. Beta-koeffisienter. Kun respondenter som svarte positivt eller negativt, er tatt med i analysen $(\mathrm{N}=766)$.

\begin{tabular}{lccc}
\hline & M1 & M2 & M3 \\
\hline Alder & $-0,01$ & 0,00 & $-0,01$ \\
Kjønn (vs. kvinne) & $0,41^{\star}$ & $0,41^{\star}$ & $0,47^{\star \star}$ \\
Utdanning (fire kategorier) & $0,28^{\star \star}$ & $0,24^{\star \star}$ & $0,19^{\star}$ \\
Levestandard (fire kategorier) & 0,05 & 0,03 & $-0,05$ \\
Sentral-Ukraina (vs. vest) & & $-0,44$ & $-0,45$ \\
Nord-Ukraina (vs. vest) & & $-0,12$ & $-0,01$ \\
Syd-Ukraina (vs. vest) & $-0,52^{\star}$ & $-0,46$ \\
Øst-Ukraina (vs. vest) & $-0,27$ & $-0,30$ \\
Urbanitetsgrad (fire kategorier) & & $-0,14^{\star}$ & $-0,16^{\star}$ \\
Institusjonstillit (indeks) & & & $0,36^{\star \star}$ \\
Interesse for lokalpolitikk (fire kategorier) & & & $0,30^{\star \star}$ \\
Lokaldemokrati-score (indeks) & & & 0,15 \\
Lokal deltakelse (indeks) & & & $-0,83$ \\
Nagelkerke $\mathbf{R}^{2}$ & $\mathbf{0 , 0 4}$ & $\mathbf{0 , 0 6}$ & $\mathbf{0 , 1 1}$ \\
\hline
\end{tabular}

${ }^{\star} \star$ Signifikant på 0,01-nivå

*Signifikant på 0,05-nivå

Først når vi introduserer de tre siste variablene i modell 3, får vi utslag som forbedrer vår evne til å predikere hvorvidt en respondent støtter eller ikke støtter reformen, forutsatt at vi kjenner vedkommendes resultat på de uavhengige variablene i modellen. Kun to av de fire nye variablene gir imidlertid statistisk signifikante utslag; viktigst er tillit til myndighetene som naturlig nok er positivt korrelert med den avhengige variabelen. Også interesse for lokalpolitikk har en statistisk signifikant effekt på oppslutning om desentraliseringsreformen, slik tabellen viser. Effekten av kjønn opprettholdes selv etter at vi har kontrollert for de nye variablene i modellen. Vi sjekket videre om ulik grad av kunnskap om reformen kunne være av betydning (kvinner rapporterer litt lavere grad av informasjon om desentraliseringsreformen enn menn), men heller ikke dette ser ut til å forklare forskjellen. Heller ikke er kvinner mer misfornøyde med resultatene av desentraliseringsreformen så langt (se under). Det må således være andre årsaker til at menn slutter sterkere opp om reformene enn kvinner, enn de som lar seg forklare ut ifra dataene i denne spørreundersøkelsen.

At desentraliseringsreformen allerede hadde gitt positive utslag på kvaliteten på myndighetsutøvelsen lokalt, bekreftes av et spørsmål om respondentene anser lokale myndigheters arbeid for å ha blitt bedre, for å være som før, eller for å ha blitt forverret etter at reformene ble påbegynt i 2015. Kun $13 \%$ sier at utviklingen har 
gått i feil retning, $39 \%$ sier det er omtrent som før mens $48 \%$ hevder at myndighetsutøvelsen er bedret. Logistisk regresjon (ikke vist her) finner at sosiodemografiske variabler har liten effekt, mens de variablene som har statistisk signifikant (positiv) effekt på vurderingen, er (i rekkefølge basert på effektens størrelse): vurdering av lokaldemokratiet; tillit til myndighetene; deltakelse i lokalpolitikken; og grad av urbanitet. Igjen er kommunens geografiske beliggenhet i Ukraina av liten betydning for respondentenes svar når vi har kontrollert for andre variabler i modellen.

\section{Diskusjon: Bidrag fra tre analytiske rammeverk}

Vår spørreundersøkelse blant innbyggere om desentralisering og lokaldemokrati i Ukraina gir et sammensatt bilde av dagens situasjon og pågående reformer. Vi har sett at folk gir et forholdsvis dystert bilde av egne muligheter til å påvirke beslutninger lokalt. Dette har nær sammenheng med manglende tillit til politikere generelt. Noe bedre er imidlertid vurderingen av myndighetenes evne til å gi informasjon om viktige saker, herunder bruk av lokale skatteinntekter, og med hensyn til hvordan de fordeler ressurser. Selv om tallene for lokal politisk deltakelse i Ukraina ikke er spesielt høye, viser undersøkelsen at et flertall er engasjert i hvert fall i én form for aktivitet lokalt (foruten valg, der også et flertall av innbyggerne deltar). Videre er det lite motstand mot, og blant mange betydelig støtte til, pågående desentraliseringsreformer, og mange ser allerede en forbedring av lokale myndigheters arbeid i perioden etter at reformene startet. Et viktig funn er også at tatt i betraktning de store regionale sosioøkonomiske, politiske og identitetsmessige skillene i Ukraina, er det forbausende små forskjeller mellom de ulike geografiske områdene med hensyn til hvordan folk vurderer lokaldemokratiet og den pågående desentraliseringsreformen.

Kan man så bruke de analytiske rammeverkene presentert over til å forstå utviklingen av det ukrainske lokaldemokratiet? Det er liten tvil om at Ukraina søker å tilpasse seg de europeiske modellene for desentralisering og lokaldemokrati i tråd med «the structural adaptation framework». Selv om mye av harmen som ble utløst under Majdan-revolusjonen i 2013-14 rettet seg mot myndighetenes vilkårlige maktutøvelse og korrupsjon, var regimets plutselige skifte med hensyn til videre europeisk integrasjon den direkte foranledningen til protestene. Landets nye politiske ledelse slo raskt inn på en ny kurs, der tettere integrasjon i de europeiske institusjoner har stått høyt på dagsorden. President Porosjenko vektla herunder allerede i sin innsettelsestale betydningen av desentralisering og lokaldemokrati, som raskt ble konkretisert i desentraliseringsreformen vedtatt i april 2015.

Ukraina er nå en aktiv partner i de europeiske nettverkene og institusjonene knyttet til lokalt selvstyre og lokaldemokrati. Vestlige internasjonale donorer, inkludert Sverige og Norge, bidrar med rådgivere og betydelig finansiell støtte til reformene. Blant annet etablerte Europarådet et ekspertisesenter med internasjonale rådgivere knyttet til programmet «Strengthening the Capacity of Local Authorities in Ukraine». Oppgavene til ekspertisesenteret bestod i å bidra til å styrke det lokale selvstyret, støtte 
arbeidet med å forbedre lovgivningen for å fremme lokaldemokratiet, samt legge til rette for desentralisering av myndighet «i overensstemmelse med bestemmelsene $\mathrm{i}$ Europeisk charter om lokalt selvstyre og beste europeiske praksis». ${ }^{6}$ Regionalministeriet, som er ansvarlig for implementeringen av desentraliseringsreformen, får videre støtte av EU og individuelle EU-land til å styrke kompetansen både nasjonalt og i regionene gjennom et målrettet program (U-LEAD with Europe). ${ }^{7}$

Lokaldemokratireformene skjer altså innenfor et rammeverk der de europeiske prinsippene for et godt lokalt selvstyre er den målestokken Ukraina ønsker å bevege seg mot. Resultatene fra vår undersøkelse antyder at det er lite motstand mot, og til dels betydelig oppslutning om, denne retningen på reformene. Samtidig som europeiske land har gått sammen om de 12 prinsippene for godt lokalstyre, er det viktig å understreke at det er store forskjeller mellom de europeiske landene med hensyn til graden av og formen på desentralisering. I en studie der Ukrainas styresett og velferdssystem blir sammenlignet med 31 EU- og EØS-land, finner Rauhut \& Lyska (2016) at det offentlige og det lokale nivået er viktigere for fordeling av velferd i Ukraina enn i flertallet av de andre europeiske landene.

«The incongruent speeds of change framework» og "The legacies framework» er imidlertid bedre egnet til å belyse de mange utfordringene knyttet til ukrainske lokaldemokratireformer som blant annet spørreundersøkelsen vår avdekker. "The incongruent speeds of change framework» viser til ulike forhold som kan bremse eller fremskynde reformer, med vekt på blant annet grunnlov, økonomisk utvikling og sivilsamfunn. Den ukrainske grunnloven av 1996 etablerte prinsippet om lokalt selvstyre i Ukraina, som ble utdypet blant annet i Loven om lokalt selvstyre (1997). Formelt sett er rammene i overensstemmelse med det Europeiske charteret vist til over. I praksis har ikke den sterke sentraliseringen av makten med dette forsvunnet. Den ble heller ytterligere befestet utover på 2000-tallet. Asymmetriske relasjoner mellom de ulike administrative nivåene, manglende pålegg overfor lokale myndigheter om å involvere innbyggerne i lokale beslutningsprosesser, manglende åpenhet og informasjon er forhold som har forhindret at prinsippene er blitt satt ut $\mathrm{i}$ livet. Å forankre den pågående desentraliseringsreformen i grunnloven har også vært problematisk fordi spørsmålet er blitt vevd sammen med statusen til de selvproklamerte republikkene i Donetsk og Luhansk. Fremdeles mangler grunnloven og annet ukrainsk lovverk en klar definisjon av ansvarsforholdet mellom de ulike administrative nivåene. Dette gjør at også andre deler av desentraliseringsreformen, som utdannings- og helsereformene, risikerer å uthules eller forsinkes (Umland mfl. 2018).

Når man skal vurdere hva som har forsinket og fortsatt kan forsinke reformene, må også sammenblandingen mellom politisk og økonomisk makt nevnes. Til tross

\footnotetext{
${ }^{6}$ Se Verkhovna Rada of Ukraine (2015) «News 2». Tilgjengelig på http://rada.gov.ua/en/news/News/ News/102996.html. Lesedato 17. oktober 2018.

${ }^{7}$ Informasjon om U-LEAD kan lastes ned fra https://donors.decentralization.gov.ua/en/project/ u-lead. Lesedato 17. oktober 2018.
} 
for til dels betydelig folkelig motstand har oligarkene og politiske klaners innflytelse vært og fortsetter å være svært fremtredende i Ukraina (Pleines 2016). Dette samfunnsproblemet gjenfinnes på alle samfunnsområder både på lokalt, regionalt og nasjonalt nivå og forhindrer reell innbyggermedvirkning. Dette forklarer mye av den lave tilliten som institusjoner og eliter er gjenstand for i det ukrainske samfunnet, og som vi så tydelige uttrykk for i undersøkelsen. Når det ukrainske parlamentet, riktignok mot protester, fortsatt reserverer en betydelig sum penger som de selv vil fordele lokalt, gjenspeiler dette tidligere praksis der lojale lokale beslutningstakere fikk finansiert lokale tiltak gjennom direkte overføringer fra sentralt nivå.

I «The incongruent speeds of change»-rammeverket vektlegges også betydningen av sivilsamfunnet og folkelig deltakelse. I den ukrainske loven om lokalt selvstyre beskrives en rekke former for innbyggermedvirkning, og mange av kommunene har innført ordninger som åpne møter med ordføreren, lokale offentlige høringer og muligheter for å henvende seg til myndighetene digitalt. I avsnittet om deltakelse så vi at slike kanaler i noen grad blir brukt av innbyggerne. Likevel er det få som har tro på at slike arenaer for kontakt med lokale myndigheter i seg selv gir reell innflytelse. Det er kvaliteten på innholdet i møtet mellom sivilsamfunn og myndigheter som avgjør om det er reell innflytelse, og her antyder lokaldemokratiundersøkelsen at lokale myndigheter har vært mer opptatt av kvantiteten på interaksjonen (dvs. antallet møter og arrangementer som de kan vise til) enn at denne skal lede til ekte folkelig medvirkning og innflytelse.

Spørreundersøkelsen vår viser at relativt få mennesker deltar aktivt i sivilsamfunnsorganisasjoner. Likevel har det ukrainske sivilsamfunnet ved flere anledninger vist seg å være robust og stilt myndighetene til ansvar for maktmisbruk (Cleary 2016). Et sterkt sivilsamfunn som også gjør seg gjeldende i små lokalsamfunn, vil utvilsomt være viktig for utviklingen av lokaldemokratiet. Vår undersøkelse viser overraskende at folk deltar mer i lokalpolitikken i mindre byer og landdistrikter enn i større byer, mens sivilsamfunnsorganisasjoner står sterkere i de større byene. Uansett tyder mye på at den energien som sivilsamfunnet viste $\mathrm{i}$ form av protester og demonstrasjoner rundt sentrale historiske begivenheter, ikke i tilstrekkelig grad er blitt konvertert til engasjement i mer dagligdags politisk virksomhet lokalt, der man må bruke dialog og finne kompromisser for å få små og mer gradvise politiske gjennomslag.

Et godt lokaldemokrati kan ikke utvikles over natten, og historiske forhold er nødvendigvis viktige for å forstå både dagens situasjon og mulighetene for vellykkede reformer i tiden framover. "The legacies framework» gir en nøkkel til å forstå hvordan historiske forhold legger føringer for den politiske utviklingen og mulighetene for reformer. Arven fra Sovjetunionen i forholdsvis nær fortid er i ukrainsk sammenheng spesielt betydningsfull (EU 2017). Fortiden er med på å forme verdier og vaner både $\mathrm{i}$ befolkningen og blant eliter. Tidligere valg og institusjonelle føringer kan legge begrensninger på dagens handlingsrom. Landets politiske kultur er også formet gjennom langvarige endringsprosesser. 
Det er viktig å merke seg at slike historiske forhold ikke bare legger begrensninger på utviklingen av lokaldemokratiet, men også kan ha positive føringer. Ukraina har historisk sett hatt forholdsvis sterke tradisjoner for lokalt demokrati (Kruglasjov 2016). I en ukrainsk kontekst er høy kompetanse hos myndigheter på ulike administrative nivåer utviklet gjennom lang tid, videre et klart fortrinn. På den annen side er en historie der stor grad av uformell praksis i myndighetsutøvelsen og betydningen av personlig uformell makt og nettverk har utviklet seg, uheldig for utviklingen av lokaldemokratiet. Forventninger om at det offentlige skal sikre innbyggernes velferd, slik tilfellet er i Ukraina og mange postsovjetiske samfunn, kan virke i begge retninger. På den ene siden kan dette bidra til at folk stiller legitime krav til myndighetene, men det kan også innebære en ambivalens med hensyn til å forstå nødvendigheten av egen deltakelse. Den historiske arven gjenspeiles sannsynligvis i mange av resultatene i lokaldemokratiundersøkelsen. Myndighetene bør være på vakt mot den misnøyen som flere av resultatene i undersøkelsen gir uttrykk for. Ikke innfridde forventninger etter flere runder med sterk folkelig mobilisering kan bevege opinionen i mer radikal retning, der populistiske og lite demokratiske bevegelser kan få større gjennomslag enn de har hatt til nå. Dette er imidlertid en utfordring Ukraina ikke er alene om.

\section{Konklusjon}

Vi har sett at i hvert fall tre av Illners fire analytiske rammeverk bidrar til forståelsen av lokaldemokrati og desentraliseringsreformer i Ukraina. Institusjonell treghet og politisk kultur som bremser reformene kan best forklares av «the legacies framework». At lokaldemokratireformer må understøttes av andre reformer, herunder grunnlovsendring, bekjempelse av korrupsjon og styrking av sivilsamfunnet, er innsikter som «the incongruent speeds of change framework» bidrar til. «The structural adaptation framework» kan forklare Ukrainas bruk av vestlig ekspertise og tilpasning til europeiske institusjoner og modeller for desentralisering og lokaldemokrati.

Jeg avskrev innledningsvis moderniseringsrammeverket, som ville forklart lokaldemokratireformene som forsinket tilpasning til «moderne» former for lokaldemokrati i «utviklede» vesteuropeiske land. Samtidig kan det ikke være tvil om at en del av diskursen rundt lokaldemokratireformene er tilbøyelig til å sette ukrainske reformer inn i en slik ramme. Ofte vektlegger både politikere og eksperter gamle historiske tradisjoner for lokaldemokrati i Ukraina, som ble brutt av de russiske og østerrikske imperier og videre, og mer inngripende, med den russiske revolusjonen og sovjetstyret, men der Ukraina nå er på vei tilbake til «normaltilstanden» blant europeiske demokratier (se f.eks. Kruglasjov 2016). Også vestlige rådgivere i Ukraina legger gjerne implisitt en lignende forståelse til grunn. Når en slik forståelsesramme er nær hegemonisk i den offentlige diskursen, vil den sannsynligvis også påvirke både retningen på og innholdet i reformene. Etter mitt syn kan dette fenomenet likevel bedre forklares gjennom å anvende «the structural adaptation framework», som er mindre normativt med hensyn til hva som er modernitet og utvikling. 


\section{AADNE AASLAND}

I artikkelen har jeg vist at den pågående desentraliseringsreformen er viktig for utviklingen av lokaldemokratiet i Ukraina. Avslutningsvis vil jeg påpeke at lokaldemokrati kun er ett av mange mål som desentraliseringsreformen er ment å fremme. Mye av debatten rundt reformene går nettopp på ansvars- og ressursfordelingen mellom de ulike nivåene og ikke på innbyggernes medbestemmelse. Slike forhold er imidlertid også viktige for innbyggernes liv og velferd. Desentraliseringsreformer kan for eksempel forbedre leveransen av sosiale tjenester gjennom at lokale politikere som vet hvor skoen trykker, får mer ressurser til fordeling. Samtidig er det også en fare for at slike reformer kan gi lokale myndigheter flere oppgaver uten at det følger tilstrekkelige ressurser med på lasset, og at de dermed bevisst kan brukes til å frigjøre nasjonale myndigheter for mye av ansvaret for forventninger som ikke blir innfridd. Lokaldemokratiundersøkelsen vår tyder på at reformene så langt har bidratt til en del reelle forbedringer lokalt. Likevel virker det som det kan ta en stund før innbyggerne, uavhengig av om de bor i den østlige eller vestlige delen av Ukraina, vil få oppleve at de selv kan ha særlig innflytelse på samfunnsutviklingen.

\section{Om artikkelen:}

Artikkelen er skrevet med finansiering fra det norske Utenriksdepartementet (prosjekt UKR-14/0013) og Norges Forskningsråd (NORRUSS Pluss-programmet, prosjektnr. 287620).

\section{Litteratur}

Aasland, Aadne, Åse Berit Grødeland \& Heiko Pleines (2012) «Trust and informal practice among elites in East Central Europe, South East Europe and the West Balkan». Europe-Asia Studies 32 (1): 115-43.

Aasland, Aadne \& Oleksii Lyska (2016) "Local democracy in Ukrainian cities: civic participation and responsiveness of local authorities». Post-Soviet Affairs 32 (2): 152-75.

AUC (2018) Hromady kazhut'. Tilgjengelig på http://auc.org.ua/sites/default/files/library/amu_2017_ua_ mista_otg_new.pdf. Lesedato 17. oktober 2018.

Baldersheim, Harald \& Pavel Swianiewicz (red.) (1996) Local Democracy and the Processes of Transformation in East-Central Europe. Boulder, CO: Westview Press.

Cleary, Laura (2016) «Half measures and incomplete reforms: the breeding ground for a hybrid civil society in Ukraine». Southeast European and Black Sea Studies 16 (1): 7-23.

Kommunaldepartementet (udatert) «Strategien for innovasjon og godt styresett på lokalt nivå». Tilgjengelig på www.regjeringen.no/globalassets/upload/krd/vedlegg/komm/lokaldemokrati/strategien_for_innovasjon_ og_godt_styresett.pdf. Lesedato 17. oktober 2018.

Ilko Kucheriv Democratic Initiatives Foundation (2018) «The dissatisfaction of Ukrainians with the current government is growing, while trust of civil activists increases». Tilgjengelig på https://dif.org.ua/en/article/ the-dissatisfaction-of-ukrainians-with-the-current-government-is-growing-while-trust-of-civil-activistsincreases. Lesedato 17. oktober 2018.

Illner, Mikhal (2003) «Devolution of government in the ex-communist countries: some explanatory frameworks Local democracy in post-communist Europe» i Harald Baldersheim, Mikhal Illner \& Hellmut Wollmann (red.) Local Democracy in Post-Communist Europe. Wiesbaden: Springer.

Kruglasjov, Anatolij (2016) «Ukrainskaja mestnaja demokratija: ot sovetskogo nasledija k evropejskoj modeli», Eastern Review 5: 25-38. Tilgjengelig på http://dspace.uni.lodz.pl/xmlui/bitstream/handle/11089/21565/ 0_3_\%5B25\%5D-38_Kruglaszow.pdf?sequence=1\&isAllowed=y. Lesedato 17. oktober 2018.

Levitas, Tony \& Jasmina Djikic (2017) Caught Mid-Stream: "Decentralization», Local Government Finance Reform, and the Restructuring of Ukraine's Public Sector 2014 to 2016. Stockholm: SKL International. 
Makarenko, Olena (2017) «Decentralisation: the mortal threat to Ukraine's entrenched elites». Euromaidan Press 7. november. Tilgjengelig på http://euromaidanpress.com/2017/11/07/decentralization-the-mortalthreat-to-ukraines-entrenched-elites/. Lesedato 17. oktober 2018.

Van der Meer, Tom \& Armen Hakhverdian (2017) «Political trust as the evaluation of process and performance: A cross-national study of 42 European countries». Political Studies 65 (1): 81-102.

Peleschuk, Dan (2017) «Ukraine's solution to saving democracy: Let the towns run themselves». Fast Forward 27 september. Tilgjengelig på www.ozy.com/fast-forward/ukraines-solution-to-saving-democracy-letthe-towns-run-themselves/81094. Lesedato 17. oktober 2018.

Pleines, Heiko (2016) «Oligarchs and politics in Ukraine». Demokratizatsiya: The fournal of Post-Soviet Democratization (24) 1: 105-27.

Rauhut, Daniel \& Oleksii Lyska (2016) Local Welfare Service Implementation in Ukraine: A Comparative Analysis with 31 EU- and EEA Countries. Oslo: NIBR.

Rojansky, Matthew \& Mykhailo Minakov (2018) «Kennan Cable No. 30: Democracy in Ukraine: Are We There Yet?» Kennan Institute 30. januar. Tilgjengelig på www.wilsoncenter.org/publication/kennan-cable-no-30democracy-ukraine-are-we-there-yet. Lesedato 19. november 2018.

Rothstein, Bo (2004) «Introduction» i János Kornai, Bo Rothstein \& Susan Rose-Ackerman (red.) Creating Social Trust in Post-Socialist Transition. New York: Springer (1-10).

Sasse, Gwendolyn (2014) «The «new» Ukraine: A state of regions», i James Hughes \& Gwendoly Sasse (red.) Ethnicity and Territory in the Former Soviet Union: Regions in Conflict. London: Routledge (69-100).

Umland, Andreas, Anthony Levitas \& Maryna Rabinovych (2018) «From amalgamation of local communities to a new governance system in post-Euromaidan". New Eastern Europe 17. juni. Tilgjengelig på http:// neweasterneurope.eu/2018/06/19/amalgamation-local-communities-new-governance-system-posteuromaidan-ukraine/. Lesedato 17. oktober 2018. 
194 | AADNE AASLAND

\section{Appendiks}

Tabell 4. Uavhengige variabler brukt i regresjonsanalysene

\begin{tabular}{|c|c|c|}
\hline & $\mathrm{N}$ & $\%$ \\
\hline \multicolumn{3}{|l|}{ Kjønn } \\
\hline Menn & 487 & 45,3 \\
\hline Kvinner & 587 & 54,7 \\
\hline \multicolumn{3}{|l|}{ Utdanning } \\
\hline Ikke avsluttet videregående & 11 & 1,0 \\
\hline Yrkesutdanning & 392 & 37,4 \\
\hline Videregående & 167 & 15,9 \\
\hline Høyere utdanning & 479 & 45,7 \\
\hline Mangler & 25 & \\
\hline \multicolumn{3}{|l|}{ Levestandard } \\
\hline Mangler alltid penger & 363 & 35,0 \\
\hline Mangler penger, men greier oss & 443 & 42,7 \\
\hline Greier oss bra & 220 & 21,2 \\
\hline Kan tillate oss alt & 12 & 1,2 \\
\hline Mangler & 36 & \\
\hline \multicolumn{3}{|l|}{ Geografisk bosted } \\
\hline Sentralt & 249 & 23,2 \\
\hline Sør & 192 & 17,9 \\
\hline Nord & 250 & 23,3 \\
\hline$\varnothing_{\text {st }}$ & 150 & 14,0 \\
\hline Vest & 233 & 21,7 \\
\hline \multicolumn{3}{|l|}{ Urbanitetsgrad } \\
\hline Landsby/rural & 278 & 25,9 \\
\hline Småby & 108 & 10,1 \\
\hline Større by & 221 & 20,6 \\
\hline Regional hovedstad & 467 & 43,5 \\
\hline \multicolumn{3}{|l|}{ Interesse for lokalpolitikk } \\
\hline Overhodet ikke interessert & 308 & 29,0 \\
\hline Lite interessert & 280 & 26,4 \\
\hline Noe interessert & 345 & 32,5 \\
\hline Veldig interessert & 129 & 12,1 \\
\hline Mangler & 12 & \\
\hline
\end{tabular}

